\title{
WW Domain-Containing Adapter Protein With Coiled-Coil
}

National Cancer Institute

\section{Source}

National Cancer Institute. WW Domain-Containing Adapter Protein With Coiled-Coil. NCI Thesaurus. Code C134036.

WW domain-containing adapter protein with coiled-coil (647 aa, $\sim 71 \mathrm{kDa}$ ) is encoded by the human WAC gene. This protein is involved in chromatin modification. 